УДК 339.13:378

\title{
ФОРМУВАННЯ SOFT SKILLS ФAХIВЦЯ \\ В ГАЛУЗІ МАРКЕТИНГУ НА ОСНОВІ КОМПЕТЕНТНІСНОГО ПІДХОДУ
}

\section{FORMATION OF SOFT SKILLS MARKETING PROFESSIONAL ON THE BASIS OF COMPETENCE APPROACH}

\author{
Мозгова Галина Валентинівна \\ кандидат економічних наук, доцент, \\ Харківський національний університет імені В.Н. Каразіна \\ ORCID: https://orcid.org/0000-0002-9763-3298 \\ Євтушенко Вікторія Анатоліївна \\ кандидат економічних наук, просресор, \\ Харківський національний університет імені В.Н. Каразіна \\ ORCID: https://orcid.org/0000-0002-7764-2277 \\ Мозгова Анастасія Дмитрівна \\ аспірант, \\ Харківський національний університет імені В.Н. Каразіна \\ ORCID: https://orcid.org/0000-0002-9836-7657
}

Mozgova Galyna, Yevtushenko Viktoriia, Mozgova Anastasia
V.N. Karazin Kharkiv National University

Стаття присвячена теоретичному обґрунтуванню системи фрормування м'яких навичок фрахівців в галузі маркетингу на основі компетентнісного підходу. Було визначено сутність та ознаки soft skills. Проведено дослідження вимог до наявності у маркетолога soft skills на ринку праці міста Харкова. Встановлено, що більшість роботодавців розуміють необхідність наявності м'яких навичок у потенційних працівників та приділяють цьому критерію суттєву увагу. Визначені soft skills, які сьогодні є найбільш затребуваними у вітчизняних роботодавців. В результаті виконаного аналізу світового досвіду розвитку навичок 21 століття в освітніх програмах, запропоновано систему soft skills фрахівця в галузі маркетингу. Визначено, що для маркетолога найважливішими soft skills (вищого порядку) $є$ критичне мислення та здатність приймати рішення, креативність, комунікабельність та кооперація (уміння працювати у команді). Саме вони дозволяють вирішувати складні професійні завдання.

Ключові слова: soft skills, м'які навички, маркетинг, фрахівець в галузі маркетингу, креативне мислення, критичне мислення, комунікабельність, командна робота.

Статья посвящена теоретическому обоснованию системы формирования мягких навыков специалистов в области маркетинга на основе компетентностного подхода. Были определены сущность и признаки soft skills. Проведено исследование требований к наличию у маркетолога soft skills на рынке труда города Харькова. Установлено, что большинство работодателей понимают необходимость наличия мягких навыков у потенциальных работников и уделяют этому критерию существенное внимание. Определены soft skills, которые сегодня являются наиболее востребованными у отечественных работодателей. В результате выполненного анализа мирового опыта развития навыков 21 века в образовательных программах, предложена система soft skills специалиста в области маркетинга. Определено, что для маркетолога важнейшими soft skills (высшего порядка) является критическое мышление и способность принимать решения, креативность, коммуникабельность и кооперация (умение работать в команде). Именно они позволяют решать сложные профессиональные задачи.

Ключевые слова: soft skills, мягкие навыки, маркетинг, специалист в области маркетинга, креативное мышление, критическое мышление, коммуникабельность, командная работа 
The development of information technology, the replacement of routine operations with artificial intelligence, the fundamental transformation of professions leads to the need to form in the marketer such skills that will allow him to adapt and be in demand in the labor market. Such skills have been found to be so-called soft skills. The study of different approaches to the formulation of soft skills and hard skills allowed to determine that the hard skills of a marketer - is the technical knowledge, skills and abilities to use modern tools for marketing management in general and perform certain functional tasks in different applications. Soft skills are a set of skills and personal characteristics of a marketer, the possession of which leads to success in the workplace. That is, having soft skills allows to use technical skills and knowledge as effectively as possible. The main features of Soft skills are highlighted: non-technical competencies; belong to a set of personality traits; difficult to measure, assessment is often subjective; permission to be successful in workplace; are not mandatory, but determine in combination with special skills the professionalism of the worker; increase work efficiency; are valuable in any workplace; useful not only for work but for daily life as well. A study of the requirements for a marketer to have soft skills in the labor market of the city of Kharkiv. It is concluded that most employers understand the need for soft skills in potential employees and pay significant attention to this criterion. Thus, in almost all vacancies, $20-30 \%$ are the requirements for the candidate to have soft skills. As a result, the most popular skills are established. The analysis of world experience of development of skills of the 21st century in educational programs is executed. As a result, a system of soft skills of a marketing specialist is proposed. Soft skills for the highest order marketer have been established, which are: critical thinking and decision-making ability, creativity, sociability and cooperation (ability to work in a team). They allow to solve complex professional problems. The identified competencies are characterized in terms of their components and the ability to assess marketing professionals.

Keywords: soft skills, marketing, marketing specialist, creative thinking, critical thinking, sociability, teamwork.

Постановка проблеми. Стрімкий розвиток технологій істотно ускладнює завдання прогнозування того, яким буде ринок праці вже через кілька років. Розвиток інфрормаційних технологій та, зокрема, штучного інтелекту призводить до того, що сьогодні складно уявити, як буде виглядати майбутня робоча сила, які будуть вимоги з боку роботодавця. Безумовно, багато зусиль витрачається на прогнозування того, які обсяги і види робот будуть затребувані, які навички будуть зайвими.

За думкою багатьох дослідників, сьогодні світ знаходиться на порозі Четвертої промислової революції. Розвиток галузей, які раніше функціонували окремо (такі як: штучний інтелект та машинне навчання, робототехніка, нанотехнології, 3D-друк, генетика та біотехнологія) розвиває та посилює нову, сучасну людину. Не зважаючи на те, що ці зміни відкривають великі перспективи для майбутнього процвітання та створення робочих місць, багато $з$ них також створюють серйозні проблеми які вимагають активної адаптації з боку корпорацій, урядів, громадськості та окремих осіб. По мірі того, як цілі галузі пристосовуються та з'являються нові, багато професій зазнають фрундаментальної трансформації. Разом технологічний, соціально-економічний, геополітичний та демографрічний розвиток та взаємодія між ними породжують нові категорії робочих місць та занять, частково або повністю витісняючи інші. Вони змінюють набір навичок, необхідних як для досвідчених, так і для нових професіоналів у більшості галузей, і трансорормують те, як і де працюють люди. Це призводить до нових проблем в управління та регулюванні [1].

Отже, важливішою проблемою стає необхідність розвитку знань і навичок, які дозволять фрахівцю адаптуватися до мінливих вимог ринку праці таким чином, щоб з одного боку максимально реалізувати свій потенціал, з іншого - бути затребуваним на ринку праці.

Аналіз останніх досліджень і публікацій. Аналіз сучасних практик відбору персоналу [2; 3; 4] показав, що вже сьогодні роботодавці все більше і більше звертають увагу на навички, які безпосередньо не пов'язані з профресійним виконанням окремих фуункцій: вміння побудувати відносини, креативний підхід до вирішення задач, адаптованість, стратегічне мислення, здатність до навчання, навички міжособистісного спілкування та інше. Стають актуальними нетрадиційні інструменти відбору персоналу, які дозволяють розкрити кандидату не тільки свої спеціальні навички, а і продемонструвати свою здатність бути відмінним товаришем по команді. 3 одного боку, це призводить до необхідності постійного удосконалення системи підбору кадрів на підприємстві. 3 іншого боку, така ситуація вимагає надання особливої уваги фрормуванню так званих «м'яких навичок» або soft skills.

Серед наукових праць, які було присвячено дослідженню soft skills у фрахівців різного профрілю можна виділити наступні:

- Делія О. [5] аналізує роль soft skills у фpopмуванні особистості сучасного управлінця та їх вплив на професійну діяльність; 
- Наход С.А. [6] обґрунтовує значущість soft skills для профресійного становлення срахівців соціологічних професій;

- Коваль К.О. [7] вивчає механізми розвитку «м'яких» навичок молоді з позиції майбутнього працевлаштування;

- Кучинова Н.М. [8] досліджує розвиток креативної складової профресійного мислення майбутніх маркетологів.

Крім того це питання вивчали такі науковці та практики бізнесу: Андрущенко С., Бондаренко О., Воронкова В., Вукіна Н.В., Дементієвська Н.П., Євтушенко В.А., Захарченко Ю.В., Клюковска І., Коляда Н., Лайл М., Лапигин Ю.Н., Леонова Е., Михайлова А.М., Пинська М.А., Сущенко І.М., Химич І.Г.

Виділення невирішених раніше частин загальної проблеми. Не зважаючи на те, що задача формування soft skills у фрахівців в галузі маркетингу $\epsilon$ актуальною та потребує вирішення, кількість наукових праць з цієї тематиці є обмеженою. Це зумовило обрання теми дослідження, визначення його мети та завдань.

Постановка завдання. Мета дослідження - теоретичне обґрунтування системи фрормування м'яких навичок фрахівця в галузі маркетингу на основі компетентнісного підходу.

Виклад основного матеріалу дослідження. Саме поняття «Soft Skills» не $\epsilon$ новим. Вперше його впровадили в армії Сполучених Штатів Америки в 1959-1972 роки 3 метою підвищення рівня підготовки військовослужбовців [9]. У 1971-1991 роках було проведено дослідження компетенцій з метою підбору співробітників до дипломатичної служби Держдепартаменту США. Як результат, з явилось поняття «компетенція» та методики її оцінки.

Компетенція - базова якість особистості, яку можна розглядати як причинну взаємозалежність ефрективного та найкращого виконання роботи на основі критеріїв. Під базовою якістю розуміється, що компетенція є частиною індивідуума, $є$ сталою та може визначати поведінку людини в будь-якій ситуації та у процесі виконання робочих задач. Причинна взаємозалежності означає, що компетенція викликає або визначає певну поведінку та виконання. На основі критеріїв - значить, що компетенція дійсно прогнозує добре чи погане виконання завдань, яке вимірюється на основі використання визначеного критерію, або стандарту [10].

Сьогодні цей досвід використовується та доповнюється в будь-якій галузі по всьому світу. Оскільки потреби ринку праці постійно змінюються, змінюються й вимоги до фрахівців. Не $€$ винятком і ринок праці маркетологів. Це призводить до необхідності подальшого дослідження та удосконалення системи формування soft skills у фрахівців в галузі маркетингу.

Але, перш за все, необхідно уточнити, що таке м'які навички. Відповісти на це основне питання непросто через те, що сприйняття того, що є м'яким вмінням, відрізняється в залежності від контексту. Одна й та ж навичка може вважатися м'якою в одній конкретній галузі, а в іншій - вважатися жорсткою.

3 метою встановлення, що $є$ м'які, а що $€$ тверді навички для маркетолога, було проведене дослідження різних підходів до визначення понять «Soft skills» (таблиця 1) та «Hard skills» (таблиця 2). Базою дослідження стали сучасні праці вітчизняних та іноземних науковців.

На основі аналізу та синтезу вище наведених визначень та додаткової літератури [1-16], було зроблено висновок, що «Hard skills» маркетолога - це професійні знання, вміння та навички використання сучасного інструментарію управління маркетинговою діяльністю, в цілому, та виконання окремих фрункціональних задач в різних сфрерах застосування.

Soft skills - сукупність навичок та особистих характеристик робітника, володіння якими призводить до досягнення успіху на робочому місці. Тобто володіння м'якими навичками дозволяє використовувати якомога ефективніше свої технічні здібності та знання.

Було виділено основні ознаки Soft skills:

- нетехнічні компетенції;

- відносяться до сукупності рис особистості;

- складно виміряти, оцінка найчастіше є суб'єктивною;

- дозволяють досягти успіху на своєму робочому місці;

- не $є$ обов'язковими, але визначають у поєднанні зі спеціальними навичками профеесіоналізм робітника;

- підвищують ефрективність роботи;

- $є$ цінними на будь-якому місці роботи;

- корисні не тільки для роботи, а й для повсякденного життя також.

Отримано висновок, що, не зважаючи на те, що soft skills менш спеціалізовані, менш прив'язані до конкретних професій і більше відповідають загальним вимогам суспільства та особистості кандидата, єдиного підходу до визначення переліку м'яких навичок не існує. 
Визначення поняття Soft skills за різними джерелами

\begin{tabular}{|c|c|}
\hline Автор & Визначення \\
\hline $\begin{array}{l}\text { Коляда Н., } \\
\text { Кравченко О. } \\
\text { [11, с. 145] }\end{array}$ & $\begin{array}{l}\text { Поряд із фраховими компетентностями визначають професійну } \\
\text { самореалізацію спеціалістів. Це: креативність, лідерські якості, уміння } \\
\text { працювати в команді, організаторські здібності, системне мислення, } \\
\text { емоційний інтелект, комунікація, робота з інформацією, мотивація. }\end{array}$ \\
\hline $\begin{array}{l}\text { Коваль К.О. } \\
\text { [7, с. } 163]\end{array}$ & $\begin{array}{l}\text { Ïх складно виміряти. Це: працелюбність, ініціативність, творчі здібності, } \\
\text { здатність до навчання, чесність тощо. Оцінка м'яких навичок має } \\
\text { суб'єктивний характер }\end{array}$ \\
\hline $\begin{aligned} \operatorname{Haxc} \\
{[6, c}\end{aligned}$ & $\begin{array}{l}\text { Характеризує виходячи з визначення: } \\
\text { - «Soft» - «гнучкість»: відсутність стереотипності, шаблонності, } \\
\text { подолання фріксованої фрункціональності, здатність до змін. } \\
\text { - «Sкіlls» - «компетентність»: здатність, готовність та можливість } \\
\text { особистості діяти у мінливих ситуаціях, спираючись на інтуїцію та } \\
\text { власний досвід. } \\
\text { Це комплекс неспеціалізованих надпрофесійних «гнучких } \\
\text { компетентностей», що впливають на успішне виконання професійних } \\
\text { обов'язків фрахівців будь-якої сфрери діяльності. }\end{array}$ \\
\hline $\begin{array}{l}\text { Клюковска І. } \\
\text { [12] }\end{array}$ & $\begin{array}{l}\text { Менш фрормалізовані в порівнянні з hard skills навички, необхідні в будь- } \\
\text { якій профресії: міжособистісне спілкування, робота в команді, навички } \\
\text { продажів, ведення презентацій та переговорів, публічних виступів і т.п. }\end{array}$ \\
\hline Де & $\begin{array}{l}\text { Це соціальні навики особистості, які можна класифрікувати на } \\
\text { міжособистісні, як взаємодія лідерських якостей, організаційні навики } \\
\text { та уміння спілкування. До них відносять комунікативні та управлінські: } \\
\text { вміння встановити міжособистісні відносини, навики переконання, } \\
\text { проведення переговорів, ораторське мистецтво та презентаційні } \\
\text { навики, здатність ведення дискусій, прийняття рішень, уміння створити } \\
\text { ефективні команди з урахуванням культурних відмінностей, можливість } \\
\text { вирішення конфрліктних ситуацій }\end{array}$ \\
\hline $\begin{array}{l}\text { Stewart C., Wall A., } \\
\text { Marciniec S. }\end{array}$ & $\begin{array}{l}\text { Нетехнічні компетенції, пов'язані з особистістю, відносинами та } \\
\text { здатністю ефективно взаємодіяти з іншими. }\end{array}$ \\
\hline $\begin{array}{l}\text { Schulz B. } \\
{[14, \text { c. } 147]}\end{array}$ & $\begin{array}{l}\text { Відносяться до сукупності рис особистості, соціальних якостей, особистих } \\
\text { звичок, доброзичливості та оптимізму, які відрізняють людей. М'які } \\
\text { навички доповнюють тверді навички, які є технічними вимогами роботи. }\end{array}$ \\
\hline $\begin{array}{l}\text { Klaus P., } \\
\text { Rohman J., } \\
\text { Hamaker M. } \\
{[15, \text { c. } 2]}\end{array}$ & $\begin{array}{l}\text { Ці навички доповнюють важкі і є важливими для успіху на робочому } \\
\text { місці. Ви можете мати усі технічні знання у світі, але якщо ви не можете } \\
\text { продавати свої ідеї, ладити з іншими або виконувати свою роботу } \\
\text { вчасно, ви нікуди не підете швидко. }\end{array}$ \\
\hline
\end{tabular}

Таблиця 2

Визначення поняття Hard skills за різними джерелами

\begin{tabular}{|c|c|}
\hline Автор & Визначення \\
\hline $\begin{array}{l}\text { Коваль К.О. } \\
{[7, \text { с. 163] }}\end{array}$ & $\begin{array}{l}\text { Характеризує як такі, що легко вимірити, дати їм об'єктивну оцінку. } \\
\text { До твердих навичок відносять професійні знання, а також вміння та } \\
\text { навички, які є необхідними для виконання маркетингових задач }\end{array}$ \\
\hline $\begin{array}{l}\text { Наход С.А. } \\
{[6, \text { с. } 132]}\end{array}$ & $\begin{array}{l}\text { Визначає як систему професійних компетенцій, які поєднують спеціальні } \\
\text { фахові та загально-дидактичні знання, фахові уміння, професійні } \\
\text { здібності та професійно важливі риси особистості. Вони відображають } \\
\text { профресійний рівень фрахівця, який можна наочно продемонструвати. }\end{array}$ \\
\hline $\begin{array}{l}\text { Клюковська I. } \\
\text { [12] }\end{array}$ & $\begin{array}{l}\text { Навички в області фрормалізованих технологій: фрінанси, аудит, логістика, } \\
\text { маркетинг і т.д. }\end{array}$ \\
\hline $\begin{array}{l}\text { Stewart C., Wall A., } \\
\text { Marciniec S. } \\
{[13, \text { c. 276] }}\end{array}$ & Технічні, матеріальні, вимірювані компетенції \\
\hline $\begin{array}{l}\text { Klaus P., Rohman J., } \\
\text { Hamaker M. } \\
{[15, \text { c. } 2]}\end{array}$ & $\begin{array}{l}\text { Технічні можливості та срактичні знання, які необхідні для виконання } \\
\text { роботи }\end{array}$ \\
\hline
\end{tabular}


Перелік необхідних навичок постійно доповнюється в залежності від змін у суспільстві та технологіях.

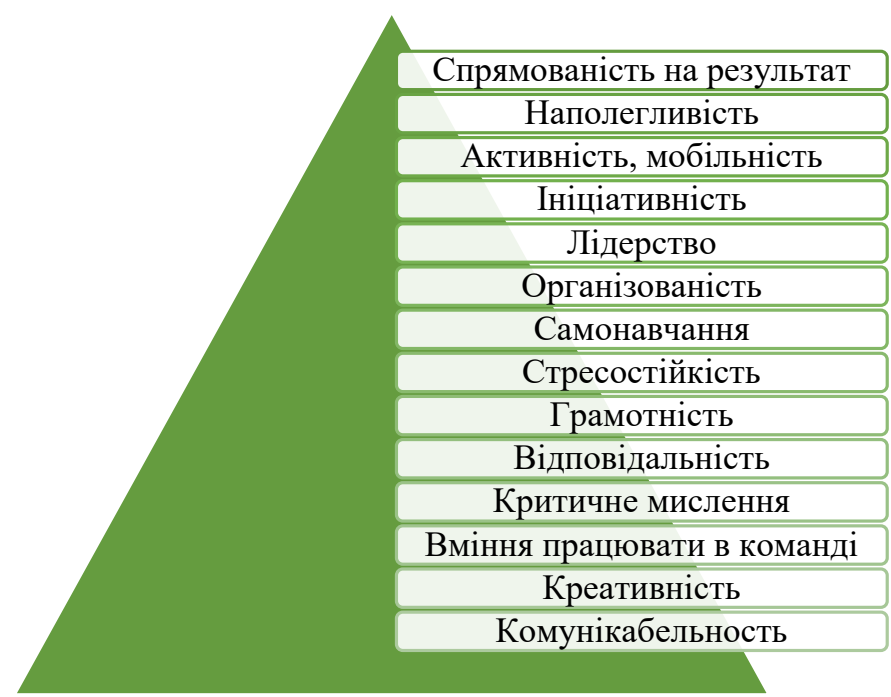

Pис. 1. Soft skills, які очікують роботодавці м. Харкова від кандидатів на отримання вакансій в сфері маркетингу Джерело: розроблено авторами
3 метою встановлення системи soft skills, які потрібно сьогодні саме маркетологам, було вивчено вакансії фрахівців в галузі маркетингу на ринку міста Харкова. В якості джерел інорормації були використані ресурси 3 розміщення вакансій: www.work.ua, www.rabota.ua, www.rabota.kharkov.ua, ua.jooble.org. Були досліджені вимоги до кандидатів на вакансії: маркетолог, менеджер 3 реклами, бренд-менеджер, контент-маркетолог, PR-менед-жер, інтернетмаркетолог, трейд-маркетолог, копірайтер, SMM-спеціаліст, мерчендайзер, креативний директор, таргетолог, маркетинговий аналітик. Результати дослідження представлено на рисунку 1.

Серед вимог до вакансій було виявлено понад 14 позицій, які можна віднести до м'яких навичок. Відсутність загальноприйнятої класифрікації Soft skills призводить до того, що кожний роботодавець формулює їх по різному. Тому для більшої наочності навички було згруповано. Так до критичного мислення було віднесено аналітичний склад розуму та стратегічне мислення, здатність приймати рішення,

Вирішення проблем

Критичне мислення

Креативність

Комунікація

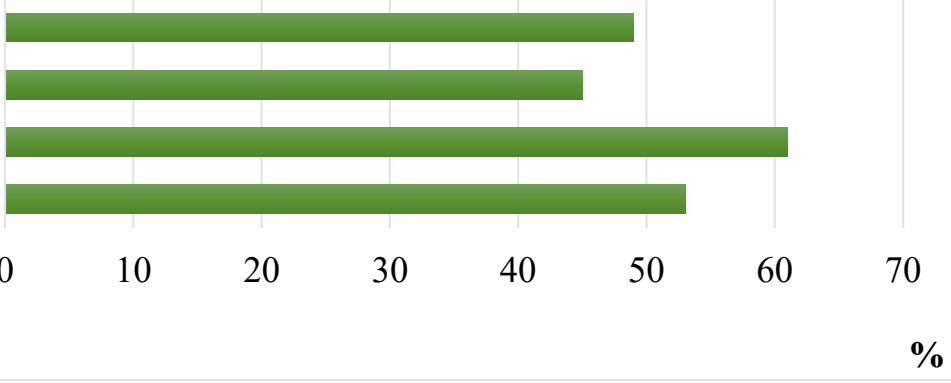

Рис. 2. Компетенції XXI століття, які є найбільш затребуваними згідно з дослідженням 152 країн, листопад 2018 р. [17]

Критичне мислення та аналіз

Вирішення проблем

Самоменеджмент

Робота $з$ людьми

Управління та комунікація діяльності

Використання та розвиток технологій

Грамотність

Фізичні здібності

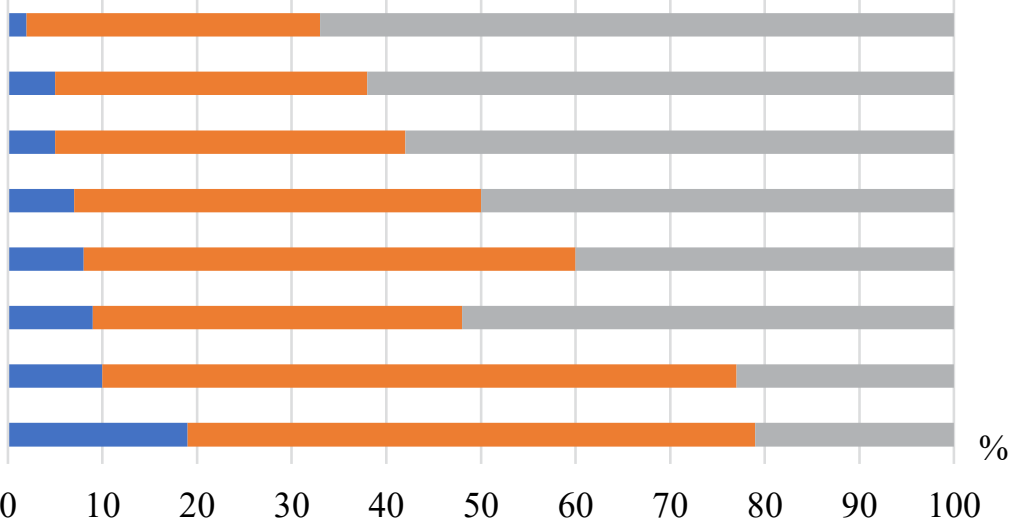

п Зменшення Стабільне $\square$ Збільшення 


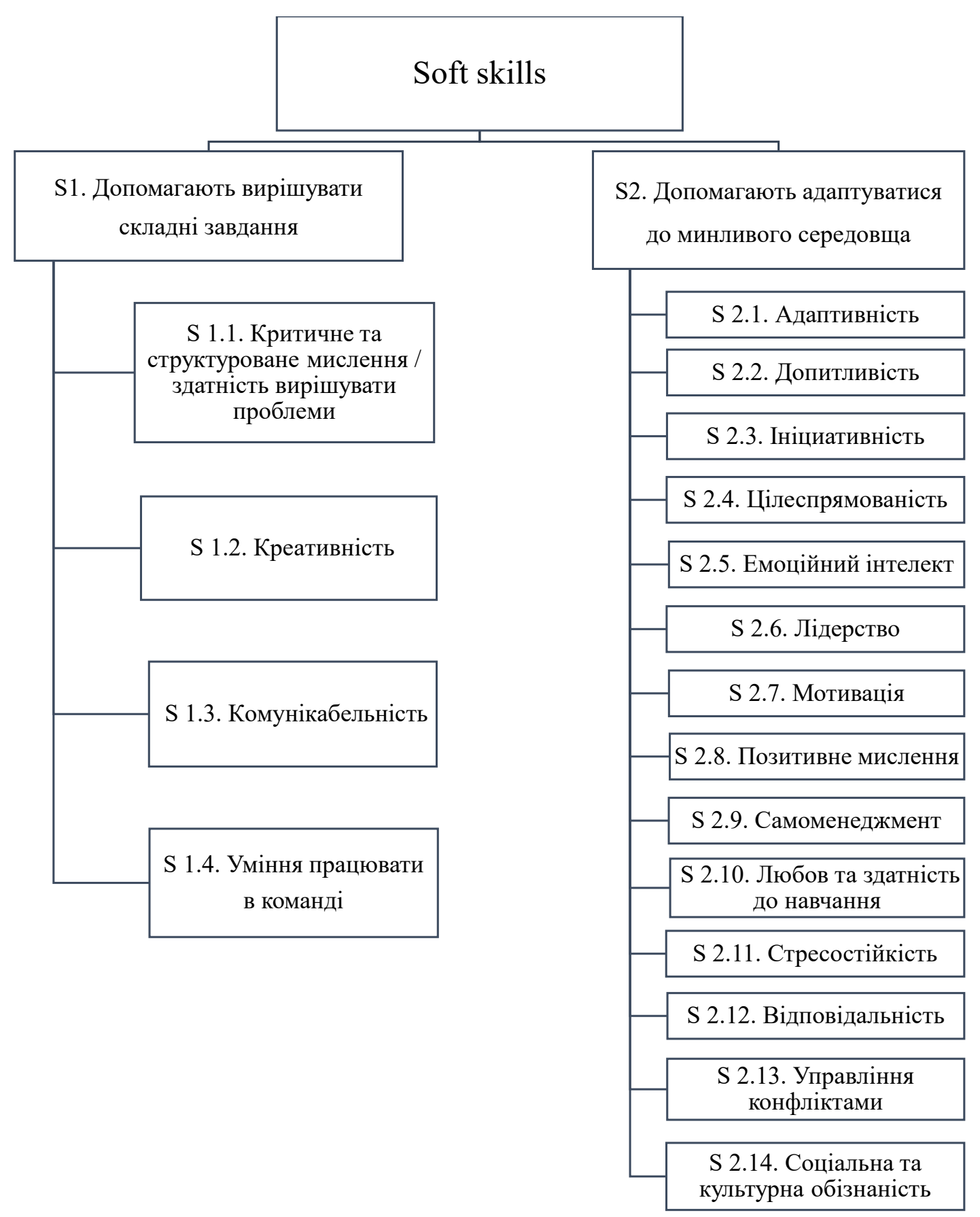

Рис. 4. Система Soft skills фахівця в галузі маркетингу

Джерело: розроблено авторами

уважність до деталей, кмітливість, сміливість, допитливість. До грамотності включено широкий кругозір, до стресостійкойсті - вміння працювати в режимі багатозадачності. До комунікабельності включено крім прямої вимоги ще ведення переговорів, презентаційні навички, емпатія.

Всі встановлені Soft skills було проранжовано від більшої кількості вимог від роботодавців (комунікабельність) до найменшої кількості нагадувань у вакансіях (спрямованість на результат).

Для того, щоби визначити систему ключових soft skills для фрахівця в галузі маркетингу та побудови класифрікації недостатньо тільки орієнтуватися на сьогоднішні вимоги ринку праці. Необхідно враховувати досвід розвинутих країн та орієнтуватися на потреби майбутнього. Для цього вивчено світовий досвід 
розвитку навичок 21 століття в освітніх програмах. Було розглянуто ряд досліджень, що мали за мету з'ясувати, на які компетенції орієнтується професійне співтовариство.

Цікавим $€$ проект Центру освіти при Інституті Брукінгу, метою якого $€$ підтримка країн у вдосконаленні оцінювання, викладання та вивчення навичок 21 століття через підвищення рівня грамотності оцінювання серед регіональних та національних зацікавлених сторін у галузі освіти [17]. В межах цього проекту було проведене дослідження у 152 країнах світу 3 приводу наявності визначення навичок у національних документах. Згідно цього дослідження найчастіше в документах про стандарти освіти говориться про такі компетенції як творчість, комунікація, критичне мислення та вирішення проблеми (рис. 2). В основі цих компетенцій лежать уява, генерування ідей, побудова аргументацій, встановлення дефріциту інфрормації та навички ії пошуку, фрормулювання власних ідей та розвиток чужих, оцінка власних пропозицій та суджень, прийняття мети груп та оцінка загальних результатів.

На рисунку 3 представлено навички та групи навичок, які роботодавці вважають зростаючими в затребуваності до 2025 року. До них входять такі групи як критичне мислення та аналіз, так і вирішення проблем, які залишаються на першому місці в порядку денному із ріка в рік.
Згідно дослідження [18] новими є навички самоуправління, такі як стійкість, активне навчання, стресостійкість та гнучкість. Крім того, в рамках зазначеного дослідження були використані дані доступні за допомогою метрик Linkedln та Coursera. Це партнерство дозволило відстежувати з безпрецедентною деталізацією типи спеціалізованих навичок, які необхідні для роботи.

На основі аналізу сучасних вимог до квалісрікації маркетолога (рис. 1), найкращого досвіду освіти в розвинутих країнах (рис. 1), наукової та практичної літератури 3 даної тематики, а також результатів сучасних досліджень (рис. 3) запропоновано систему Soft skills фрахівця в галузі маркетингу (рис. 4).

Висновки. В процесі дослідження було визначено що найбільш важливими soft skills для маркетолога $€$ : критичне мислення та здатність приймати рішення, креативність, комунікабельність та кооперація (уміння працювати у команді). Саме вони дозволяють вирішувати складні професійні завдання. їх відносять до компетентностей вищого порядку. Безумовно, це групи навичок, до структури яких входять сукупність інших менших навичок. Розвиток другої групи soft skills направлено на отримання можливості бути адаптивним до будь-яких змін середовища, в якому працює фрахівець в галузі маркетингу.

\section{СПИСОК ВИКОРИСТАНИХ ДЖЕРЕЛ:}

1. The Future of Jobs Employment, Skills and Workforce Strategy for the Fourth Industrial Revolution. World Economic Forum. URL: http://reports.weforum.org/future-of-jobs-2016/

2. Кудінова М.М., Євтушенко В.А., Лазарєва К.О. Інноваційні методи відбору персоналу в сучасних умовах. Східна Європа. Економіка, бізнес та управління. 2017. № 3(08). С. 158-164.

3. Bates H. 11 Effective Employee Selection Methods To Start Using Today. 2020. URL: https://harver.com/blog/ employee-selection-methods/

4. Sullivan J. 12 Effective Ways to Assess Candidates' Soft Skills. URL: https://business.linkedin.com/talentsolutions/blog/interview-questions/2017/assessing-soft-skills-is-one-of-the-biggest-interviewing-challenges-hereare-12-ways-to-overcome-it

5. Делія О. Особистість керівника як чинник ефеективного управління. Економічний аналіз. 2012. T. 11(2). C. 187-189.

6. Наход С.А. Значущість «Soft skills» для профресійного становлення майбутніх фрахівців соціономічних профресій. Науковий часопис Національного педагогічного університету імені М.П. Драгоманова. Серія 5 : Педагогічні науки: реалії та перспективи. 2018. № 63. С. 131-135.

7. Коваль К.О. Розвиток «soft skills» у студентів - один з важливих чинників працевлаштування. Вісник Вінницького політехнічного інституту. 2015. № 2. С. 162-167

8. Кучинова Н.М. Розвиток креативної складової професійного мислення майбутніх маркетологів : дис. ... канд. психол. наук : 19.00.07. Київ, 2017. 248 с.

9. Що таке hard skills i soft skills: як нас оцінює роботодавець. URL: https://eduhub.in.ua/news/shcho-takehard-skills-i-soft-skills-yak-nas-ocinyuye-robotodavec

10. Спенсер Л., Спенсер С. Компетенции на работе. Пер. с англ. Москва, 2009. 384 с.

11. Коляда Н., Кравченко О. Практичний досвід фрормування «soft-skills» в умовах закладу вищої освіти. Актуальні питання гуманітарних наук. 2020. № 3(27). С. 137-145. 
12.Клюковская И. Функциональных навыков уже недостаточно? URL: http://www.management.com.ua/ notes/soft_skills.html

13. Stewart C., Wall A., Marciniec S. Mixed signals: Do college graduates have the soft skills that employers want? In Competition Forum. American Society for Competitiveness. 2016. Vol. 14. No. 2. P. $276-281$.

14. Schulz B. The importance of soft skills: Education beyond academic knowledge. Nawa Journal of Communication. 2008. № 2(1). P. 146-154.

15. Klaus P., Rohman J., Hamaker M. The hard truth about soft skills. HarperCollins Publishers. 2009.205 p.

16. Yevtushenko V. A. Manager of corporate social responsibility: institutionalization and professional competence. International journal of experimental education. 2014. № 4-2. P. 84-88. URL: https://www.expeducation.ru/ru/article/ view?id=5103

17. Care E., Kim H., Vista A., Anderson K. Education System Alignment for 21st century skills: Focus On Assessment. Brookings institution. 2018. 41 p. URL: https://www.brookings.edu/wp-content/uploads/2018/11/ Education-system-alignment-for-21st-century-skills-012819.pdf

18. The Future of Jobs Report 2020. World Economic Forum. URL: http://www3.weforum.org/docs/WEF_Future_ of_Jobs_2020.pdf

\section{REFERENCES:}

1. The Future of Jobs Employment, Skills and Workforce Strategy for the Fourth Industrial Revolution (2016). World Economic Forum. Retrieved from: http://reports.weforum.org/future-of-jobs-2016/

2. Kudinova, M.M., Yevtushenko, V.A., \& Lazarjeva, K.O. (2017). Innovacijni metody vidboru personalu v suchasnykh umovakh [Innovative Methods of the Staff Selection in the Modern Conditions]. Skhidna Jevropa. Ekonomika, biznes ta upravlinnja - Eastern Europe: Economy, Business And Management, 3(08), 158-164. Retrieved from: http://www.easterneurope-ebm.in.ua/journal/8_2017/30.pdf (in Ukrainian)

3. Bates, H. (2020). 11 Effective Employee Selection Methods To Start Using Today. Retrieved from: https://harver.com/blog/employee-selection-methods/

4. Sullivan, J. (2017). 12 Effective Ways to Assess Candidates' Soft Skills. Retrieved from: https://business.linkedin.com/talent-solutions/blog/interview-questions/2017/assessing-soft-skills-is-one-of-the-biggest-interviewing-challenges-here-are-12-ways-to-overcome-it

5. Delia, O. (2012). Osobystistj kerivnyka jak chynnyk efektyvnogho upravlinnja [Identity of the Director as a Factor of HR-Management]. Ekonomichnyj analiz - Economic Analysis, 11(2), 187-189. Retrieved from: http://nbuv.gov.ua/UJRN/ecan_2012_11\%282\%29_38 (in Ukrainian)

6. Nakhod, S.A. (2018). Znachushhistj «Soft skills» dlja profesijnogho stanovlennja majbutnikh fakhivciv socionomichnykh profesij [Importance of "Soft Skills" for Professional Formation of Future Specialists of Socionomic Professions]. Naukovyj chasopys Nacionaljnogho pedaghoghichnogho universytetu imeni M.P. Draghomanova. Serija 5: Pedaghoghichni nauky: realiji ta perspektyvy - Scientific journal of M.P. Dragomanov National Pedagogical University. Series 5: Pedagogical Sciences: Realities and Perspectives, 63, 131-135. Retrieved from: http://enpuir.npu.edu.ua/handle/123456789/23921 (in Ukrainian)

7. Koval, K.O. (2015). Rozvytok «soft skills» u studentiv - odyn z vazhlyvykh chynnykiv pracevlashtuvannja [Development of "soft skills" for students is one of important factors of employment]. Visnyk Vinnycjkogho politekhnichnogho instytutu - Visnyk of Vinnytsia Polytechnical Institute, 2, 162-167. Retrieved from: https://visnyk.vntu.edu.ua/index.php/visnyk/article/view/827/826 (in Ukrainian)

8. Kuchynova, N.M. (2017). Rozvytok kreatyvnoji skladovoji profesijnogho myslennja majbutnikh marketologhiv [The Development of the Creative Component of Future Marketing Specialists' Professional Thinking]. Candidate's thesis. Kyiv. (in Ukrainian)

9. Shho take hard skills i soft skills: jak nas ocinjuje robotodavecj [What are hard skills and soft skills: how we are evaluated by the employer]. Retrieved from: https://eduhub.in.ua/news/shcho-take-hard-skills-i-soft-skills-yak-nasocinyuye-robotodavec (in Ukrainian)

10. Spencer, L., \& Spencer, S. (2009). Kompetencii na rabote [Competence at Work]. Moscow: Hippo Publishing Ltd. (in Russian)

11. Koliada, N., \& Kravchenko, O. (2020). Praktychnyj dosvid formuvannja «soft-skills» v umovakh zakladu vyshhoji osvity [Practical Experience of "Soft-Skills" Formation in Terms of Higher Education Institution]. Aktualjni pytannja ghumanitarnykh nauk - Humanities science current issues, 3(27), 137-145. https://doi.org/10.24919/23084863.3/27.203686 (in Ukrainian)

12. Kljukovskaja, Y. (2007). Funkcional'nyh navykov uzhe nedostatochno? [Functional skills are no longer enough?]. Retrieved from: http://www.management.com.ua/notes/soft_skills.html (in Russian) 
13. Stewart, C., Wall, A., \& Marciniec, S. (2016). Mixed signals: Do college graduates have the soft skills that employers want? In Competition Forum. American Society for Competitiveness, 14(2), 276-281. Retrieved from: https://www.researchgate.net/publication/316066488

14. Schulz, B. (2008). The importance of soft skills: Education beyond academic knowledge. Nawa Journal of Communication, 2(1), 146-154. DOI: 10.1016/0006-3207(93)90452-7

15. Klaus, P., Rohman, J., \& Hamaker, M. (2009). The hard truth about soft skills. HarperCollins Publishers.

16. Yevtushenko, V.A. (2014). Manager of corporate social responsibility: institutionalization and professional competence. Mezhdunarodnyj zhurnal eksperimental'nogo obrazovaniya - International journal of experimental education, 4(2), 84-88. Retrieved from: https://www.expeducation.ru/ru/article/view?id=5103

17. Care, E., Kim, H., Vista, A., \& Anderson, K. (2018). Education System Alignment for 21st century skills: Focus On Assessment. Brookings institution. Retrieved from: https://www.brookings.edu/wp-content/uploads/2018/11/Education-system-alignment-for-21st-century-skills-012819.pdf

18. The Future of Jobs Report 2020 (2020). World Economic Forum. Retrieved from: http://www3.weforum.org/ docs/WEF_Future_of_Jobs_2020.pdf 